\title{
Brainstem ischemic syndrome in juvenile NF2
}

John W. Henson, MD, FAAN, Tara Benkers, MD, and Connor McCormick, MD

Neurol Genet 2020;6:e446. doi:10.1212/NXG.0000000000000446
Correspondence

Dr. Henson

john.henson@swedish.org

\section{Abstract}

\section{Objective}

A new case of brainstem ischemic necrosis in a young woman with de novo neurofibromatosis type 2 (NF2) is reported, and given notable similarities to 7 prior cases of brainstem stroke in the literature, features defining a possible syndrome were sought.

\section{Methods}

Case review including detailed clinical assessment, neuroimaging analysis, genetic testing, and brain biopsy, followed by a multicase analysis.

\section{Results}

Brainstem ischemia in juvenile NF2 typically occurs in teenagers without previously known $\mathrm{NF} 2$ as an acute, monophasic presentation with restricted diffusion in the midbrain or pons following a recent hypoperfusion event, normal vascular imaging, obvious intracranial imaging features of NF2, typical inactivating NF2 alterations, biopsy showing necrosis without small vessel pathology, and subsequent aggressive NF2 lesion progression.

\section{Conclusions}

Brainstem ischemia in juvenile NF2 is a rare syndrome of unclear etiology, possibly reflecting an unknown underlying vascular abnormality; a digenic effect is not excluded.

From the Swedish Neurofibromatosis Center (J.W.H); Ben and Catherine Ivy Center for Advanced Brain Tumor Treatment (J.W.H., T.B.); and University of Washington School of Medicine (C.M.), Seattle. 


\section{GLOSSARY}

ADC = apparent diffusion coefficient; CPM = central pontine myelinolysis; NF2 = neurofibromatosis type 2.

Neurofibromatosis type 2 (NF2) usually presents in patients in their early 20 s with symptoms related to vestibular schwannomas. Younger age at onset occurs in nearly $20 \%$ of patients with NF2, however, and in these patients, nonvestibular presentations predominate, including visual symptoms (cataracts, retinal hamartoma, or optic nerve sheath meningioma), cutaneous lesions (NF2 skin plaques, cutaneous schwannomas, or hyperpigmented lesions), transient mononeuropathy of cranial nerves, seizures (often with focal cortical dysplasia), and symptomatic spinal nerve root

Figure 1 Radiographic features of the case
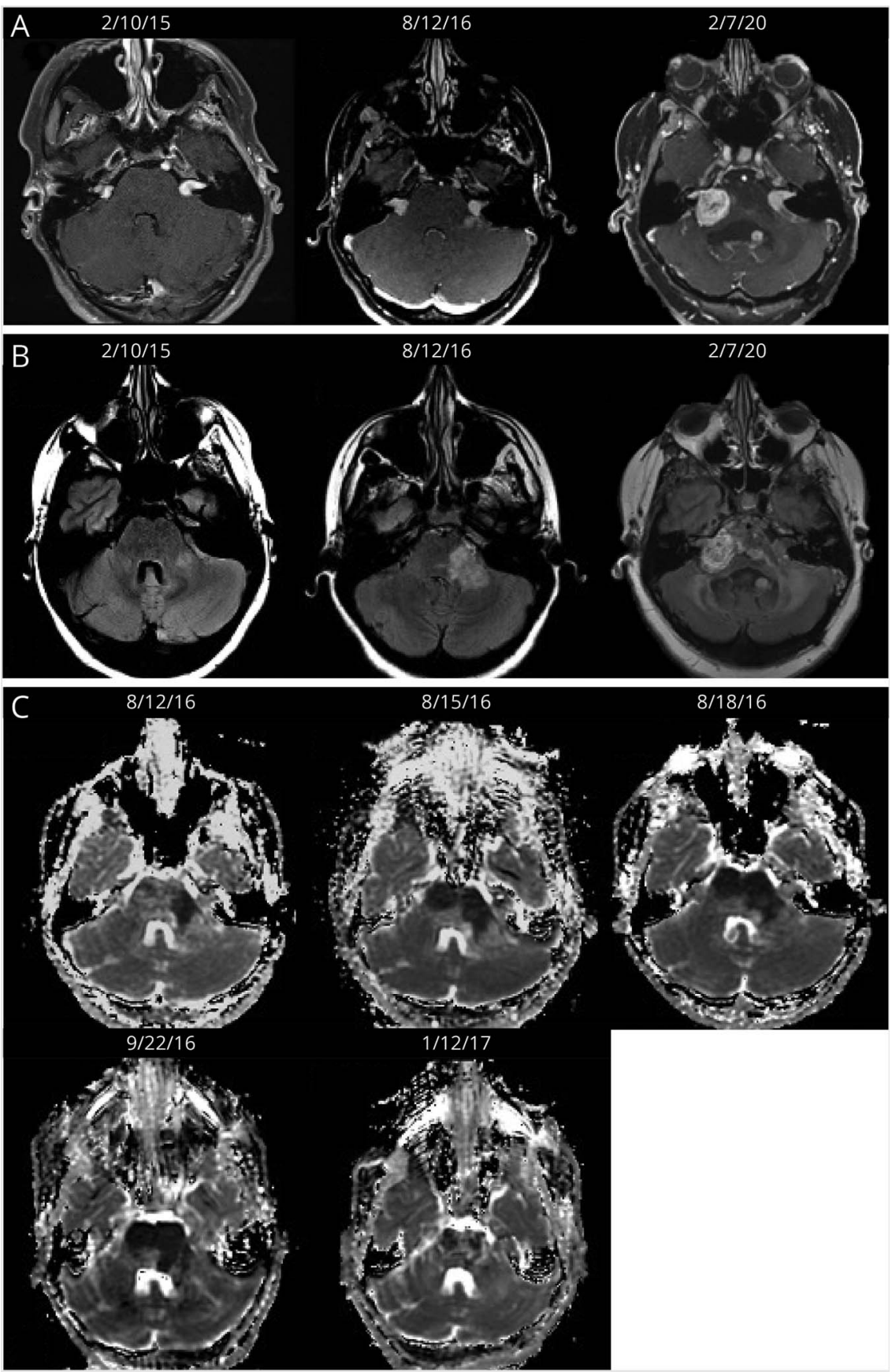

(A) Aggressive growth pattern of tumors. Note the enhancement in the left middle cerebellar peduncle on August 12, 2016, in the region of T2weighted signal change. (B) T2 fluid attenuation inversion recovery changes across time. The earlier lesion in 2015 has enlarged and shows enhancement. Biopsy in this region showed necrosis but was negative for tumor or infection. (C) Time course of spreading ADC changes. The duration of depressed ADC is atypically long compared with the phasic pattern usually seen in acute stroke. ADC = apparent diffusion coefficient. 
schwannomas. ${ }^{1,2}$ We recently encountered a patient with progressive brainstem necrosis, as shown on serial diffusionweighted images and by biopsy. Seven prior published cases had marked similarities, suggesting an underrecognized syndrome in NF2.

\section{Methods}

We performed a detailed case review including clinical and neuroimaging analyses, genetic testing, and brain biopsy. Multicase analysis was undertaken to observe common features in 16 predetermined categories. ${ }^{3-6}$

\section{Results}

\section{Clinical data}

A 25-year-old woman with a history of strabismus surgery in childhood developed episodes of vertigo. After 6 months of persistent symptoms, imaging revealed bilateral vestibular and other cranial nerve schwannomas, multiple meningiomas and a cervical cord ependymoma, as well as several small focal white matter lesions in the corona radiata. There was a subtle, nonenhancing focus of T2-weighted hyperintensity in the $\mathrm{L}$ middle cerebellar peduncle on a December $2015 \mathrm{MRI}$, adjacent to a subsequent area of restricted diffusion (figure 1). There was no family history of NF2, although the parents were not tested or imaged. Single gene testing of blood lymphocytes detected a germline NF2 variant, c.288_ 290delCTT, which deletes a highly conserved proline residue and is thought to inactivate merlin. A large left lumbar schwannoma raised concern for malignant peripheral nerve sheath tumor and was partially resected via an abdominal approach. There was substantial blood loss requiring transfusion and volume support. Ten days later, she developed progressive slurred speech, left facial numbness, bilateral hand weakness, and difficulty walking. Blood pressure and serum sodium were normal. She progressed to a locked-in syndrome over 4 days with some residual eye movements. Serial MRIs revealed a multifocal, bilateral, spreading area of markedly hypointense apparent diffusion coefficient (ADC) signal (0.3 $\left.\times 10^{-3} \mathrm{~mm}^{2} / \mathrm{s}\right)$ in the pons and left middle cerebellar peduncle (figure 1). At the site of the prior T2 signal change in the left middle cerebral peduncle, there was subtle enhancement where $\mathrm{ADC}$ was less decreased. Vascular imaging, including CT angiogram and a catheter angiogram, showed a basilar artery diameter of $3.9 \mathrm{~mm}$ at the mid pons and a basilar bifurcation at the level of the dorsum sellae (figure 2, $\mathrm{A}$ and $\mathrm{B}$ ) and was midline throughout, thus not meeting a definition of dolichoectasia. ${ }^{7-9}$ The anatomy of the basilar artery did not change as seen 5 years later on the $2020 \mathrm{MRI}$ study. Serial ADC maps showed prolonged loss of signal over time rather than the typical phasic pattern seen after ischemic stroke. Perfusion maps suggested decreased cerebral blood volume and cerebral blood flow in the lesion (data not presented). CSF showed a WBC of 5 cells per $\mathrm{mm}^{3}$ but was otherwise normal including nucleic acid amplification tests for viral infection. Biopsy of the left middle cerebellar peduncle in

\section{Figure 2 Vascular imaging}

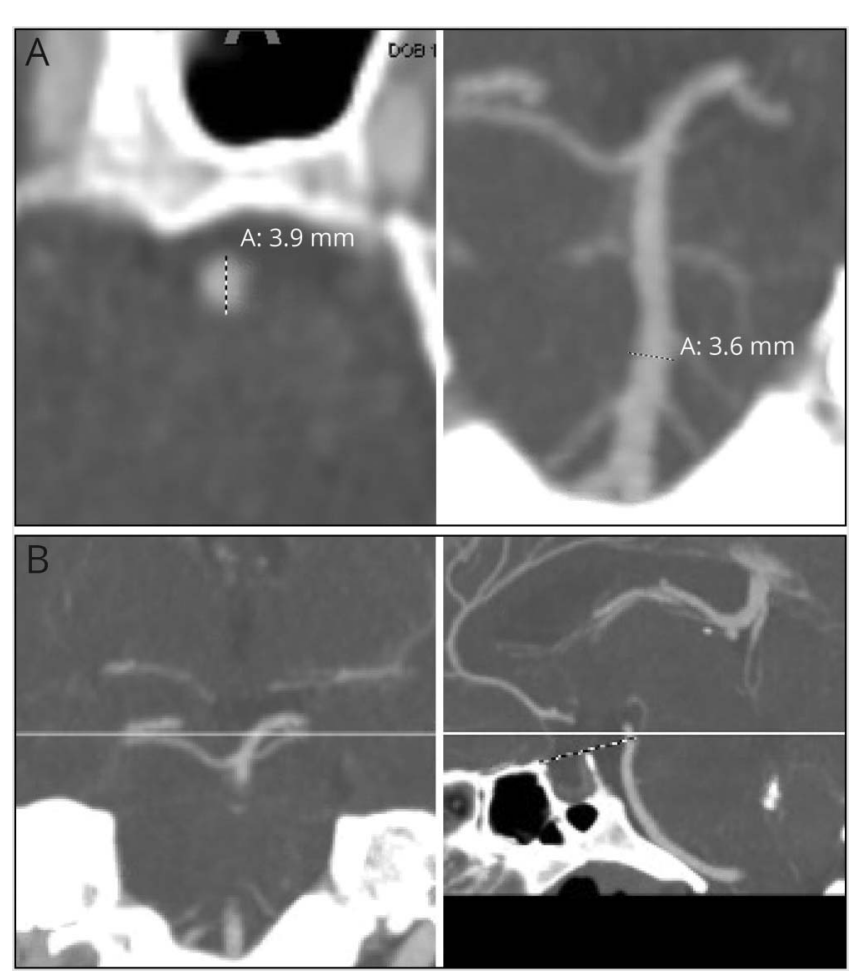

(A) Diameter of the basilar artery at mid pons. The maximal diameter of $3.9 \mathrm{~mm}$ did not meet the $4.5-\mathrm{mm}$ threshold for dolichoectasia. The course of the basilar artery was midline. (B) Tip of the basilar artery. The basilar artery bifurcated at the level of the dorsum sellae and thus did not meet the criteria for elongation. Note the persistent right fetal posterior cerebral artery.

the area of initial enhancement revealed white matter, which varied from near-normal to necrotic. Within the latter, there was evidence of axonal swelling, mild macrophage infiltration, and scant lymphocytes. Luxol fast blue-Periodic acid-Schiff stain showed focal loss of myelin staining but with some fragments showing normal myelin. No vascular pathology was identified. PCR analysis of tissue for infection was negative. Fluorodeoxyglucose-PET 1 month after the onset showed hypometabolism in the pons. Subsequent MRIs demonstrated some persistent restricted diffusion as well as encephalomalacia of the basis pontis and rapid growth of multiple NF2-related tumors. Four years later, the patient is locked-in except for upgaze and is deaf in both ears. A mammalian target of rapamycin inhibitor was started in an attempt to suppress further growth of the tumors. ${ }^{10,11}$

\section{Syndrome features}

Table 1 shows the findings of 8 cases with regard to 16 predetermined categories of clinical, imaging, genetic, and pathologic features. $^{3-6}$ In addition, a 2019 article from a UK group described 2 pediatric patients, without clinical details, who had pontine infarcts. One had renal artery stenosis and coarctation of the aorta, and a second had vertebral artery stenosis and a $22 \mathrm{q}$ microdeletion. ${ }^{12}$ Table 2 shows an analysis of the NF2 variants reported in each case. Overall, the similarities between cases are striking. 
Table 1 Features of the syndrome

\begin{tabular}{|c|c|c|}
\hline Major features & Cases $(n=8)$ & $\begin{array}{l}\text { Syndrome average }(95 \% \\
\mathrm{Cl})\end{array}$ \\
\hline Sex & & $60 \%$ female \\
\hline Male & 2 & \\
\hline Female & $3^{a}$ & \\
\hline Unknown & 3 & \\
\hline Age at dx NF2, y & $2,4,6,7,13,13,22,25^{\mathrm{a}}$ & $11.5(4.5-18.5)$ \\
\hline $\begin{array}{l}\text { Age at brainstem event, } \\
\text { y }\end{array}$ & $2,4,7,13,13,15,22,25^{a}$ & $12.6(5.5-19.5)$ \\
\hline Genetic alteration & $\begin{array}{l}\text { c.114G>A (splice donor, VUS); c.115-1G>C (null); c.169C>T (null); NF1 neg; c.288_290delCTT"; } \\
\text { c.447+1G>A (null); c.448-1G>A (null); frameshift, exon 12; deletion exon2 }\end{array}$ & Typical null variants in NF2 \\
\hline De novo & $Y, Y^{b}, Y^{b}, Y^{b}, Y^{b}, Y^{b}, Y^{a} ; N$ & Usually de novo \\
\hline Severity of NF2 & $\mathrm{M} ; \mathrm{S}, \mathrm{S}, \mathrm{S}, \mathrm{S}, \mathrm{S}, \mathrm{S}, \mathrm{S}, \mathrm{S}^{\mathrm{a}}$ & Severe \\
\hline Unusual lesions for NF2 & $\mathrm{N}, \mathrm{N}, \mathrm{N}, \mathrm{N}, \mathrm{N}, \mathrm{N} ; \mathrm{Cb} \mathrm{Ca}++$, No VS, E, cauda; white matter lesions ${ }^{\mathrm{a}}$ & Occasional \\
\hline $\begin{array}{l}\text { Brainstem compression } \\
\text { by VS at event }\end{array}$ & $\mathrm{N}, \mathrm{N}, \mathrm{N}, \mathrm{N}, \mathrm{N}, \mathrm{N}, \mathrm{N}, \mathrm{N}^{\mathrm{a}}$ & No \\
\hline Precipitating event & Diarrhea; fever, cough; menorrhagia; blood loss after pelvic surgery ${ }^{a}$; no; NR, NR, NR & $\begin{array}{l}\text { Yes, possibly } \\
\text { hypoperfusion }\end{array}$ \\
\hline Onset & $\mathrm{AM}, \mathrm{AM}, \mathrm{AM}, \mathrm{AM}, \mathrm{AM}, \mathrm{AM} ; \mathrm{AP}$; asymptomatic & Acute, monophasic \\
\hline $\begin{array}{l}\text { Localization in } \\
\text { brainstem }\end{array}$ & & $\begin{array}{l}\text { Left-sided predominant } \\
\text { pons, midbrain }\end{array}$ \\
\hline Midbrain & $\mathrm{MB}, \mathrm{MB}, \mathrm{MB}$ & \\
\hline Pons & $P, P, P, P, P, P^{a}$ & \\
\hline Medulla & MD & \\
\hline Unilateral & $\mathrm{U}, \mathrm{U}, \mathrm{U}$ & \\
\hline Bilateral & $\mathrm{B}^{\mathrm{a}}$ & \\
\hline Left & $L, L, L, L, L^{a}$ & \\
\hline Right & $R, R, R^{a}$ & \\
\hline Clinical severity & $M, M, M, M ; S, S, S, S^{a}$ & Mild to severe \\
\hline HTN at onset & $N, N, N, N, N, N, N^{a} ; N R, N R$ & No \\
\hline Vascular imaging & $\mathrm{Neg}$, Neg, Neg, Neg, Neg, Nega; narrowing left ICA; small left MCA & $\begin{array}{l}\text { Normal; rarely narrowed } \\
\text { lumen ICA or MCA }\end{array}$ \\
\hline Stroke blood testing & Neg, Neg, Neg, Neg, Neg, Nega; NR, NR & Negative \\
\hline Biopsy features & Reactive astrogliosis, microglia, hyalinized large caliber vessels; necrosis, vessels normal ${ }^{a}$ & Necrosis; vessels normal \\
\hline \multicolumn{3}{|c|}{$\begin{array}{l}\text { Abbreviations: } \mathrm{AM}=\text { acute monophasic; } \mathrm{AP}=\text { acute progressive; } \mathrm{B}=\text { bilateral; } \mathrm{Cb}-\mathrm{Ca}++=\text { cerebellar calcification; } \mathrm{Cl}=\text { confidence interval; } \mathrm{E}=\text { ependymoma; } \\
\text { HTN = hypertension; ICA = internal carotid artery; } \mathrm{M}=\text { mild; } \mathrm{MB}=\text { midbrain; } \mathrm{MCA}=\text { middle cerebral artery; } \mathrm{MD}=\text { medulla; } \mathrm{N}=\mathrm{no} ; \mathrm{Neg}=\text { negative; } \mathrm{NR}=\text { not } \\
\text { reported; } \mathrm{P}=\text { pons; } \mathrm{S}=\text { severe; } \mathrm{U}=\text { unilateral; } \mathrm{VS}=\text { vestibular schwannoma. } \\
\text { a Present case. } \\
\text { b Likely but not explicitly stated. }\end{array}$} \\
\hline
\end{tabular}

To summarize the data, the syndrome of brainstem necrosis in juvenile NF2 typically occurs in teenagers without previously known NF2 as an acute, typically monophasic event in the midbrain or pons. Some patients have had a recent hypoperfusion event. MRI shows markedly restricted diffusion in the lesion, but vascular imaging is normal. Our case demonstrated evolution of imaging findings and showed some unusual features compared with acute stroke. NF2 imaging features are apparent at the time of diagnosis. Typical null NF2 alterations are seen, and absence of family history in most cases suggests a de novo mutation. Biopsy in 2 cases, including ours, shows necrosis without small vessel pathology. The early-onset, high number of NF2-related lesions at diagnosis and the subsequent rapid growth suggest an 
Table 2 Analysis of alterations

\begin{tabular}{|c|c|c|c|c|}
\hline Alteration & Effect & ACMG variant classification $^{16,17}$ & $\begin{array}{l}\text { gnomAD allele } \\
\text { frequency }\end{array}$ & $\begin{array}{l}\text { MutationTaster binary } \\
\text { prediction }^{18}\end{array}$ \\
\hline c. $114 G>A$ NM_000268.4 $4^{a}$ & $\begin{array}{l}\text { Alteration within used splice } \\
\text { site }\end{array}$ & Pathogenic: PVS1, PM1, PM2, BP4 & $0 \%$ & Disease causing \\
\hline $\begin{array}{l}\text { c.115-1G>C NM } \\
000268.4^{\mathrm{a}}\end{array}$ & $\begin{array}{l}\text { Alteration within used splice } \\
\text { site }\end{array}$ & Pathogenic: PVS1, PM2, PP3 & $0 \%$ & Disease causing \\
\hline c. $169 C>T$ NM_000268.4 ${ }^{\mathrm{a}}$ & Nonsense & $\begin{array}{l}\text { Pathogenic: PVS1, PM1, PM2, PP3, } \\
\text { PP5 }\end{array}$ & $0 \%$ & Disease causing \\
\hline $\begin{array}{l}\text { c.288_290delCTT }{ }^{\mathrm{b}} \mathrm{NM}_{-} \\
000268.4\end{array}$ & $\begin{array}{l}\text { Substitution of highly } \\
\text { conserved proline }\end{array}$ & $\begin{array}{l}\text { Likely pathogenic: PM1, PM2, } \\
\text { PM4, PP3, PP5 }\end{array}$ & $0 \%$ & Disease causing \\
\hline $\begin{array}{l}\text { c.447+1G>A NM } \\
000268.4^{\mathrm{a}}\end{array}$ & $\begin{array}{l}\text { Alteration within used splice } \\
\text { site }\end{array}$ & Pathogenic: PVS1, PM2, PP3 & $0 \%$ & Disease causing \\
\hline $\begin{array}{l}\text { c.448-1G>A NM_ } \\
000268.4^{\mathrm{a}}\end{array}$ & $\begin{array}{l}\text { Alteration within used splice } \\
\text { site }\end{array}$ & Pathogenic: PVS1, PM2, PP3 & $0 \%$ & Disease causing \\
\hline Frameshift, exon 12 & Truncating & NA & NA & NA \\
\hline Deletion exon 2 & Truncating & NA & NA & NA \\
\hline
\end{tabular}

Abbreviations: ACMG = American College of Medical Genetics; gnomAD = Genome Aggregation Database; NA = not available .

a Probable transcript but not explicitly stated in reference.

b Current case.

aggressive form of NF2 in these patients as is often seen in younger patients.

\section{Discussion}

There are remarkable similarities between the cases in the literature and our patient, and this suggests a discrete clinical syndrome of which pediatric neurologists and stroke neurologists should be aware. The name brainstem ischemic syndrome in juvenile NF2 is proposed for this rare syndrome.

Our patient seems to have the most clinically devastating course of those reported to date, and despite the similarities in the cases, there are some distinctive features, which may be of value. Our patient was of somewhat older age. Gradual progression over 4 days to a severe neurologic syndrome with spreading restricted diffusion, rather than the monophasic courses reported before, is also unusual. Perfusion imaging in our patient showed low cerebral blood flow and blood volume in the pons, but it was difficult to be certain that ischemia was the cause of the perfusion changes, and the bilateral progression, the atypically long phasic course of the restricted diffusion, and the absence of vascular findings on imaging and biopsy argue against ischemia as the cause. The known focus of abnormal T2-weighted hyperintensity in the left middle cerebellar peduncle that was adjacent to the restricted diffusion had enlarged at the time of presentation and showed enhancement, and this seemed likely to represent a tumor, but biopsy of the area did not support this. Acute vacuolization of myelin, including that seen with central pontine myelinolysis (CPM), can produce restricted diffusion but not usually to the degree found in these cases. The asymmetric distribution of lesions in the pons was also not consistent with CPM, and there was no electrolyte abnormality. Delayed hypoxic leukoencephalopathy can show a long course of markedly restricted diffusion, but has not been described in the brainstem, and the preceding events in the patients here were not consistent with this mechanism. An infectious process seems unlikely given the benign CSF profile and negative PCR testing. Finally, our patient had deletion of a highly conserved proline rather than the truncating mutation more commonly seen in the other cases and in patients with NF2 in general. Nonetheless, this deletion likely produced a loss of function in merlin in common with null mutants.

There have been rare cases in which angiographic narrowing of the internal carotid artery, ${ }^{6}$ middle cerebral artery (with middle cerebral artery infarct), ${ }^{13}$ vertebral artery, ${ }^{12}$ aorta, ${ }^{12}$ or renal artery ${ }^{14}$ has been seen in NF2, leading those authors to propose a vascular process. Although well known in NF1, vasculopathy is not clearly recognized in young patients with NF2 at this time. ${ }^{1,2,12}$ Progressive brainstem stroke syndromes have been seen with dolichoectasia of the basilar artery in NF1. ${ }^{15}$ Our patient did not meet the criteria for dolichoectasia. It is notable that these brainstem ischemic events occur in such close anatomic proximity to the uniquely selective development of vestibular schwannomas in NF2. Given the rarity of the syndrome of brainstem ischemic syndrome in juvenile NF2, it is possible that a digenic process is at work. One of the literature reports analyzed the NF1 gene and found no alterations. Whole-exome sequencing would be a reasonable consideration in these cases.

\section{Acknowledgment}

James M. Scanlan, $\mathrm{PhD}$, provided assistance with statistics. 


\section{Study funding}

No targeted funding reported.

\section{Disclosure}

The authors report no disclosures. Go to Neurology.org/NG for full disclosures.

\section{Publication history}

Received by Neurology: Genetics March 21, 2020. Accepted in final form April 22, 2020.

\section{Appendix Authors}

\begin{tabular}{lll}
\hline Author & Location & Role \\
\hline $\begin{array}{l}\text { John W. } \\
\text { Henson, MD }\end{array}$ & $\begin{array}{l}\text { Swedish Neurofibromatosis } \\
\text { Center }\end{array}$ & $\begin{array}{l}\text { Study concept and author } \\
\text { of the first draft }\end{array}$ \\
\hline $\begin{array}{l}\text { Tara } \\
\text { Benkers, }\end{array}$ & $\begin{array}{l}\text { Ivy Center for Advanced } \\
\text { MD }\end{array}$ & $\begin{array}{l}\text { Clinical management of } \\
\text { the patient and input on } \\
\text { the manuscript }\end{array}$ \\
\hline $\begin{array}{l}\text { Institute } \\
\text { Connor } \\
\text { McCormick, }\end{array}$ & $\begin{array}{l}\text { University of Washington } \\
\text { School of Medicine }\end{array}$ & $\begin{array}{l}\text { Identification of literature } \\
\text { cases and input on the } \\
\text { manuscript }\end{array}$ \\
\hline
\end{tabular}

\section{References}

1. Anand G, Vasallo G, Spanou M, et al. Diagnosis of sporadic neurofibromatosis type 2 in the paediatric population. Arch Dis Child 2018;103:463-469.

2. Gaudioso C, Listernick R, Fisher MJ, Campen CJ, Paz A, Gutmann DH. Neurofibromatosis 2 in children presenting during the first decade of life. Neurology 2019;93: e964-e967.

3. Ng J, Mordekar SR, Connolly DJA, Baxter P. Stroke in a child with neurofibromatosis type 2. Eur J Paediatr Neurol 2009;13:77-79.
4. Sreedher G, Panigrahy A, Ramos-Martinez SY, Abdel-Hamid HZ, Zuccoli G. Brachium pontis stroke revealing neurofibromatosis type-2.J Neuroimaging 2013;23: 132-134.

5. Gugel I, Mautner VF, Kluwe L, Tatagiba MS, Schumann MU. Cerebrovascular insult as presenting symptom of neurofibromatosis type 2 in children, adolescents, and young adults. Front Neurol 2018;9:733.

6. Lascelles K, Afridi S, Siddiqui A, Hemingway C, Ferner R, Ganesan V. Cerebral vasculopathy in childhood neurofibromatosis type 2: cause for concern? Dev Med Child Neurol 2018;60:1285-1288.

7. Smoker WR, Price MJ, Keyes WD, Corbett JJ, Gentry LR. High-resolution computed tomography of the basilar artery: 1 . Normal size and position. Am J Neuroradiol 1986 ; $7: 55-60$.

8. Smoker WR, Corbett JJ, Gentry LR, Keyes WD, Price MJ, McKusker S. High resolution computed tomography of the basilar artery: 2. Vertebrobasilar dolichoectasia: clinical-pathologic correlation and review. Am J Neuroradiol 1086;7: $61-72$.

9. Forster A, Ssozi J, Al-Zghloul M, Brockmann MA, Keri HU, Groden C. A comparison of CT/CT angiography and MRI/MR angiography for imaging of vertebrobasilar dolichoectasia. Clin Neuroradiol 2014;24:347-353.

10. Goutagny S, Raymond E, Esposito-Farese M, et al. Phase II study of mTORC1 inhibition by everolimus in neurofibromatosis type 2 patients with growing vestibular schwannomas. J Neurooncol 2015;122:313-320.

11. Karajannis MA, Legault G, Hagiwara M, et al. Phase II study of everolimus in children and adults with neurofibromatosis type 2 and progressive vestibular schwannomas. Neuro Oncol 2014;16:292-297.

12. Halliday D, Emmanouil B, Vassallo G, et al. Trends in the phenotype in the English paediatric neurofibromatosis type 2 cohort stratified by genetic severity. Clin Genet 2019;96:151-162.

13. Ryan A, Hurley M, Brennan P, Moroney JT. Vascular dysplasia in neurofibromatosis type 2. Neurology 2005;65:163-164.

14. Cordeiro NJV, Gardner KR, Huson SM, et al. Renal vascular disease in neurofibromatosis type 2: association or coincidence? Dev Med Child Neurol 2006;48:58-59.

15. Giannantoni NM, Broccolini A, Frisullo G, et al. Neurofibromatosis type 1 associated with vertebrobasilar dolichoectasia and pontine ischemic stroke. J Neuroimaging 2015;25:505-506.

16. Richards S, Aziz N, Bale S, et al. Standards and guidelines for the interpretation of sequence variants: a joint consensus recommendation of the American College of Medical Genetics and Genomics and the Association for Molecular Pathology. Genet Med 2015; 17:405-424.

17. Kopans C, Tsiolkas V, Kouris A, et al. VarSome: the human genomic variant search engine. Bioinformatics 2018;25:1978-1980.

18. Schwarz JM, Cooper DN, Schuelke M, et al. MutationTaster2: mutation prediction for the deep-sequencing age. Nat Methods 2014;11:361-262. 


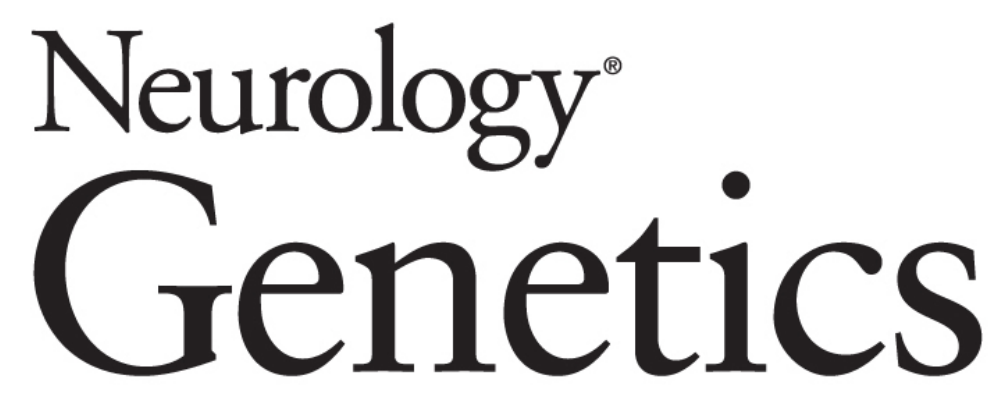

Brainstem ischemic syndrome in juvenile NF2

John W. Henson, Tara Benkers and Connor McCormick

Neurol Genet 2020;6;

DOI 10.1212/NXG.0000000000000446

This information is current as of June 16, 2020

\section{Updated Information \&} Services

\section{References}

Subspecialty Collections

Permissions \& Licensing

\section{Reprints}

including high resolution figures, can be found at: http://ng.neurology.org/content/6/4/e446.full.html

This article cites 18 articles, 2 of which you can access for free at: http://ng.neurology.org/content/6/4/e446.full.html\#\#ref-list-1

This article, along with others on similar topics, appears in the following collection(s):

Childhood stroke

http://ng.neurology.org//cgi/collection/childhood_stroke

Neurofibromatosis

http://ng.neurology.org//cgi/collection/neurofibromatosis

Stroke in young adults

http://ng.neurology.org//cgi/collection/stroke_in_young_adults

Information about reproducing this article in parts (figures,tables) or in its entirety can be found online at:

http://ng.neurology.org/misc/about.xhtml\#permissions

Information about ordering reprints can be found online: http://ng.neurology.org/misc/addir.xhtml\#reprintsus

Neurol Genet is an official journal of the American Academy of Neurology. Published since April 2015, it is an open-access, online-only, continuous publication journal. Copyright Copyright @ 2020 The Author(s). Published by Wolters Kluwer Health, Inc. on behalf of the American Academy of Neurology.. All rights reserved. Online ISSN: 2376-7839.

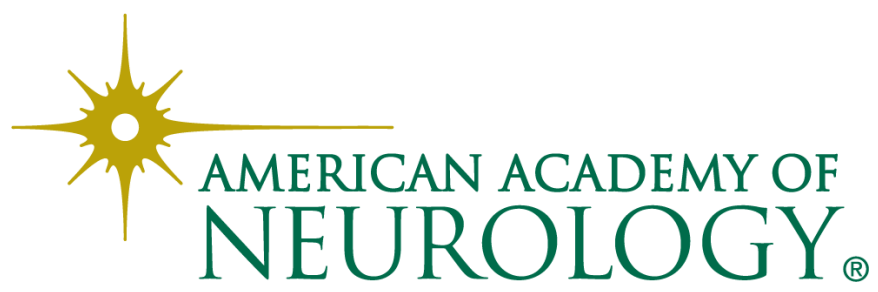

